\title{
CHEMICAL AND MINERALOGICAL ASSESSMENT OF CLAYS FROM PELOPONNESE (S. GREECE) AND THEIR EVALUATION FOR UTILIZATION IN CERAMICS INDUSTRY
}

\author{
Michailidis K., Trontzios G. and Sofianska E. \\ Aristotle University, Department of Mineralogy-Petrology-Economic Geology 54124 Thessaloniki, Greece, \\ kleopas@geo.auth.gr
}

\begin{abstract}
Mineral constituents, particle size and chemistry of ceramic raw materials may control the way ceramic products are formed and fired. Three compound (combined mixtures of 20 raw samples) clay samples from Chanakia area, Pelloponnese (S. Greece), were mineralogically and chemically investigated and their utilization as raw materials for the ceramic industry was evaluated. These samples come from different clay formations, they have red, blue and green colors and constitute the raw materials for a local brick plant. Particle size distribution analysis showed that the percentage of clay size fraction $(d<2 \mu \mathrm{m})$ ranges from 28.3 to $36.3 \mathrm{wt} . \%$. X-ray diffraction analysis revealed that the main mineral constituents are quartz, micas, feldspars (plagioclases, orthoclase), calcite (except the red - clay) and clay minerals (discrete illite, mixed - layered illite/smectite, chlorite and traces of smectite and vermiculite). Projection of their bulk chemistry on some triangular discrimination diagrams has aided us to evaluate their suitability for ceramics production, namely majiolica (earthenware), cottoforte, gres and bricks were evaluated. In conclusion, all the studied materials are proved unsuitable for high quality ceramic products. Specifically, the blue and green clays were found suitable for earthenware ceramics as are high porosity building bricks, roofing tiles and similar products, while the red clay is appropriate for gres ceramics as are the low porosity tiles and bricks.
\end{abstract}

Key words: Clays, mineralogy, chemistry, bricks, tiles, ceramics.

\section{Introduction}

A ceramic product is a material that has been fired to at least $468.3^{\circ} \mathrm{C}$ (Mitchell, 1983). In addition to being one of our earliest manufacturing and construction materials, ceramic products are among the earliest records of civilization (Austin, 1994). At present, many ceramics are manufactured from mixtures of earth materials which are shaped by compaction and sintered at high temperature.

A wide range of such materials can be transformed into ceramic products, although relatively only few of them make up most of the available resources used for the production of the ceramics offered in today's markets (Burst, 1991). The utilization of specific and well defined materials is a prerequisite for the production of high quality ceramic products (Kromer, 1982; Buhmann et al., 1988; Nakagawa, 1994). Natural clays having specific properties are used for the production of earthenware (faience), semigres (cottoforte) and gres ceramics, as these products are described by the International Association for the study of clays (Veniale and Palmonari, 1974). Water absorption (WA) is the parameter which, according to EN 100 (AFNOR EN 100,1982), defines the class to which 
any ceramic ware belongs. Thus, the fired ceramics (end products) are classified as "faience" with 16-22 wt.\% WA, "semigres" with 12-19 wt.\% WA and "gres" with WA<4 wt.\%. In the category of faience and semigres ceramics, are included, among other products, building bricks as well as roof and floor tiles, while in the category of gres, the low porosity tiles and bricks.

Clays and shales are the most widespread ceramic materials in terms of both occurrence and number of mines and plants. Clays that are commonly used for building ceramic products (bricks, roof and floor tiles etc) and coarse earthenwares are usually lean continental sediments, containing different proportions of silt and fine sand, while their clay fraction is usually less than $25 \%$ of the total material (Veniale and Palmonari,1974). The characteristics of clays for building ceramics are not easily defined since they have wide tolerances in their chemical and physical properties. Although the range of natural clays is wide, there are certain requirements concerning their ingredients, in relation to their application. To select the appropriate raw materials, users are always looking for specific criteria, which are related either to the behaviour during the various stages of manufacturing and/or to the overall mineral and chemical composition. Generally, clay-based ceramic raw materials must contain a certain proportion of clay minerals to develop the required plasticity, a proportion of filler (or skeleton formers) materials as quartz, clay, or large fragments of feldspars to prevent excessive shrinkage on drying and firing, and a proportion of fluxes (or glass formers) as are some minerals containing alkalies, magnesium, calcium or iron as fine particles (Mitchell, 1983).

Each ceramic product requires clays having particular and appropriate characteristics. They must not contain a swelling phase and their loss of weight and shrinkage, after drying and firing, have to be low (Austin, 1994; Nahdi et al., 2001). The knowledge of the mineralogical phase composition and especially the clay fraction of the raw materials used for the preparation of ceramic mixtures is of paramount importance for understanding of the technological properties of ceramic products and optimization of firing cycles in production (Teixeira et al., 2001,2004; Aras, 2004; Ferrari and Gualtieri, 2006)

The mineral content of natural ceramic raw materials controls the way ceramic products are formed and fired. Besides, both the chemical content and crystallite size of constituent minerals affect the response of materials to the firing process, while the elemental composition and the distribution of these elements within raw materials affect the nature of fired products. During the firing process of ceramic raw materials, a series of transformations occur on mineral that will be decisive for establishing the final properties of the ceramic products (Burst and Hughes, 1994; Jordán et al., 2001). Thus, mineral constituents, particle size and chemistry of ceramic raw materials may control the way ceramics are formed and fired (Teixeira et al., 2001). For this purpose, different diagrams have been empirically established on the basis of the grain size or the bulk chemistry to discriminate the suitability of a raw material for the production of various ceramics (Sandrolini and Palmonari, 1974; Vincezini and Fiori, 1976; Schmidt-Reinholz and Schmidt, 1985).

As a function of the extraction process, several raw materials, stemming from different sites of the clay deposits are mixed together in the formulation of ceramic pastes. This may originate a wide range of technical, and industrial problems, since the properties of green bodies and ceramics such as color, mechanical strength, water adsorbtion, linear contractions during drying and firing cycles is affected by both physical and chemical characteristics as average texture and mineralogical composition (Teixeira et al., 2001). Thus, a detailed characterization of these clay deposits may provide a good help to the local ceramic industries.

Previous investigations (Perraki, 1987; 1990; Perraki and Orfanoudaki 1996; Sikalidis and Minopoulos, 1998; Kastrinaki et al., 2004) referred on the evaluation of some Greek clays and mudstones for 
the ceramic industry. In W. Peloponnese extensive sedimentary clay deposits are widely used as raw materials for structural red ceramics by local ceramic industries. Furthermore, although there is a great commercial interest in ceramic faience no research has conducted on these clay deposits.

The aim of this study is to investigate the potential use of these clays for the production of ceramic wares on the basis of their particle size, mineral constituents and bulk chemistry.

\section{Materials and methods}

Samples studied in the present work come from clay formations which are under exploitation by the "ARISTEIDOPOULOS BRICK" local brick factory, at Chanakia $(9 \mathrm{~km}$ on the national road PyrgosPatras). These formations are shallow water sediments and typically constitute the lower parts of a Pliocene sedimentary sequence, including fine sands, sandy and clayey deposits. Field observations at the quarry revealed that the clay formations are differentiated, as regard the color, along the depth varying from red at the upper parts to green in the middle and blue at the deeper parts. This distinction in color is attributed to the oxidation state of the iron minerals.

Three compound samples (combined mixtures of 20 raw samples) from the different color clays were collected. In order to assure representative samples, not less than $10 \mathrm{Kg}$ were collected. The raw clays from the quarry were preliminary well homogenized. The three clays are referenced on the basis of their color and labelled as RC (red), GC (green) and BC (blue).

Prior to mineralogical and chemical analyses aliquots of about $0.5 \mathrm{Kg}$ from each well homogenized sample were disaggregated by grinding in a tungsten mortar for only one minute (Jackson, 1974; Brown and Brindley, 1980). Consequently, 20g splits of each sample were chemically treated, according to the method of Jackson (1974, see also Michailidis et al., 1993), for particle size distribution analyses. Eight size fraction ( $>125 \mu \mathrm{m}, 125-63,63-32,32-20,26-16,8-4,4-2$ and $\mathrm{d}<2 \mu \mathrm{m})$ were separated by gravity and centrifugation (Tanner and Jackson, 1947) and estimated as wt.\%.

In the sequence, random and oriented mounts were prepared, from bulk clay and the different size fractions for XRD analysis. All the oriented mounts were reanalyzed after ethylene-glycol solvation and heating at $550^{\circ} \mathrm{C}$ for $2 \mathrm{~h}$ to distinguish the expandable mineral phases and some were treated with dimethylsulphoxide (DMSO) to resolve kaolinite and chlorite peaks. XRD analysis was done using a Philips X-ray diffractometer (PW 1730) with Ni-filtered $\mathrm{Cu} \mathrm{K} \alpha$ radiation. Semi-quantitative estimate of the abundances of the minerals were made from the XRD data using the methods of Moore and Reynolds (1997)

The chemical analysis of the bulk clays was performed by atomic absorption spectrophotometry (AAS) using a Perkin Elmer model 3000 apparatus. International geostandards (clay IPT-28, terrigenous clay OOPE-101) provided by Centre de Recherches Pétrographiques et Géochimiques (CRPG) were used as reference materials. Ignition loss was calculated by firing the clays in an oven at $1100^{\circ} \mathrm{C}$.

\section{Results and discussion}

\subsection{Particle size distribution analysis}

From the particle size distribution analysis of the studied clays (Table 1) results that the blue clay has the higher amount in the clay size fraction (36.3 wt.\%) and the lower $(0.8 \mathrm{wt} . \%)$ in the sand fraction. This feature may increase the plasticity of this clay. In general, the flexural strength and other mechanical properties of ceramics are a function of the particle size distribution and clay com- 
Table 1. Grain size distribution (wt.\%) of the three compound clay samples

\begin{tabular}{|c|c|c|c|c|}
\hline Sample & $\begin{array}{c}\mathbf{d} \mathbf{6 3 \mu m} \\
(\text { sand) }\end{array}$ & $\begin{array}{c}\mathbf{d = 6 3 - 2} \boldsymbol{\mu m} \\
(\text { silt })\end{array}$ & $\begin{array}{c}\mathbf{d}<\mathbf{\mu m} \\
\text { (clay) }\end{array}$ & $\begin{array}{c}\text { C.O.I. } \\
\mathbf{\%}\end{array}$ \\
\hline RC (red) & 7.7 & 60.2 & 32.1 & 2.0 \\
\hline GC (green) & 7.9 & 63.8 & 28.3 & 15.3 \\
\hline BC (blue) & 0.8 & 62.9 & 36.3 & 16.0 \\
\hline
\end{tabular}

${ }^{1}$ Total percentage of carbonates + organics + iron oxides

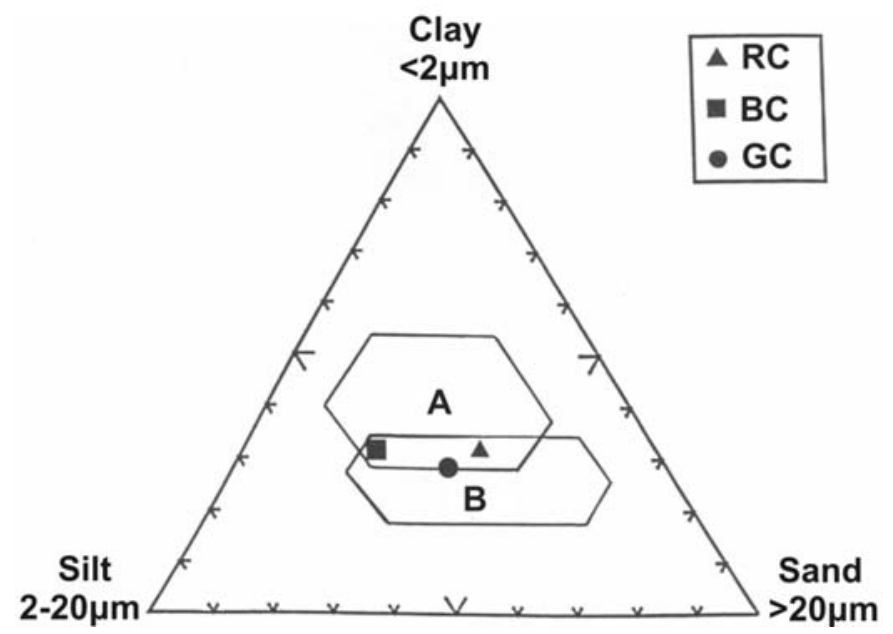

Fig. 1: Evaluation of the clay samples on the basis of their grain size distribution. The fields of roof tiles (A) and bricks (B) are also depicted (after Schmidt-Reinholz and Schmidt, 1985).

position. A low sand concentration is a determining factor to obtain ceramics with high flexural strength (Teixeira et al., 2001). All samples have nearly the same amounts of the silt-size fraction $(\mathrm{d}=32-2 \mu \mathrm{m})-60.2$ to $63.8 \mathrm{wt} . \%$. Coarse-grained materials increase drying rate, decrease excessive plasticity, and reduce shrinkage and cracking (Mitchell, 1983).

The data of the particle size distribution analysis for the studied clays were depicted in the ternary diagram of Schmidt-Reinholz and Schmidt (1985). From this diagram (Fig. 1) results that all the three clays are suitable for bricks and roof tiles because they are plotted in the overlapping fields of these ceramic wares.

\subsection{Mineralogical composition of clay samples}

X-ray diffraction analyses of whole rock samples (Fig. 2A) as well as for the 32-20 $\mu \mathrm{m}, 20-2 \mu \mathrm{m}$ and $<2 \mu \mathrm{m}$ size fraction showed that the major minerals constituents are quartz, micas, calcite (except $\mathrm{RC}$ ), feldspars (plagioclases and orthoclase), and clay minerals. Iron minerals are present in the form of pyrite and/or goethite in the three clays. Clay-size particles of the three clays consist dominantly (Fig. 2B) of discrete illite and mixed layered illite/smectite (I/S). Chlorite was identified in the GC and BC clays, while smectite and vermiculite were found in the RC. Semi-quantitative abundances of the minerals (Table 2) show that the RC clay is more quartzitic, while the $\mathrm{GC}$ and $\mathrm{BC}$ clays are more calcareous. 

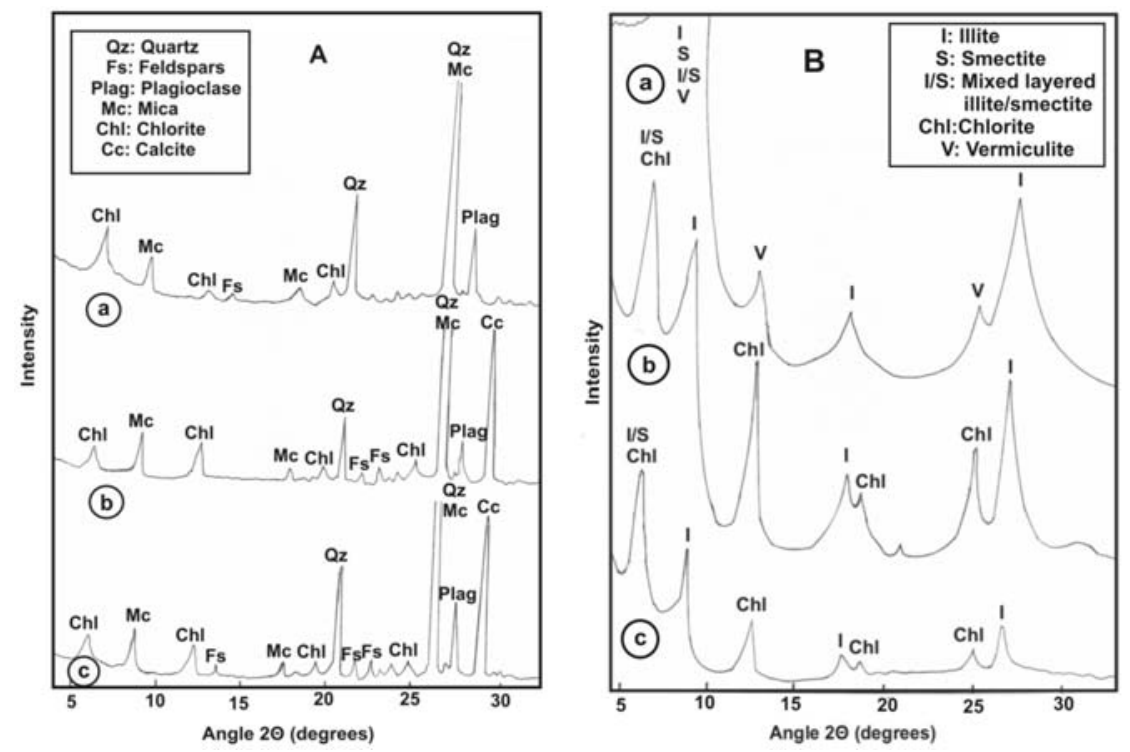

Fig. 2: X-ray diffractogramms of the total clay samples (A) and the $<2 \mu \mathrm{m}$ fraction (B) of the studied clays (a: red clay, b: green clay, c: blue clay).

Table 2. Semiquantitative mineralogical analyses of the three compound clay samples

\begin{tabular}{|c|c|c|c|c|c|c|c|c|c|c|c|}
\hline Sample & $Q z$ & Fs & Plag & $M c$ & Chl & $C c$ & $I$ & $I / S$ & $S$ & Chl & $V$ \\
\hline \multicolumn{12}{|c|}{ Red Clay (RC) } \\
\hline Total sample & **** & \multicolumn{2}{|c|}{$* *$} & ** & $* *$ & $\mathrm{Tr}$ & & & & & \\
\hline $32-20 \mu \mathrm{m}$ & $* * * *$ & $*$ & $* * *$ & ** & $\mathrm{Tr}$ & // & & & & & \\
\hline $20-2 \mu \mathrm{m}$ & **** & $*$ & ** & ** & $* *$ & /I & & & & & \\
\hline$<2 \mu \mathrm{m}$ & & & & & & & + & + & + & \pm & + \\
\hline \multicolumn{12}{|c|}{ Green Clay (GC) } \\
\hline Total sample & $* * *$ & \multicolumn{2}{|c|}{$* * *$} & ** & ** & *** & & & & & \\
\hline $32-20 \mu \mathrm{m}$ & **** & $*$ & $* * *$ & *** & $*$ & /I & & & & & \\
\hline $20-2 \mu \mathrm{m}$ & **** & $*$ & ** & $* * *$ & *** & $/ /$ & & & & & \\
\hline$<2 \mu \mathrm{m}$ & & & & & & & + & + & - & + & - \\
\hline \multicolumn{12}{|c|}{ Blue Clay (BC) } \\
\hline Total sample & ** & $* * *$ & $* *$ & $* *$ & *** & & & & & & \\
\hline $32-20 \mu \mathrm{m}$ & **** & $*$ & $* * *$ & *** & $*$ & $/ /$ & & & & & \\
\hline $20-2 \mu \mathrm{m}$ & **** & $*$ & ** & $* * *$ & *** & // & & & & & \\
\hline$<2 \mu \mathrm{m}$ & & & & & & & + & + & - & + & - \\
\hline
\end{tabular}

\section{Key}

\begin{tabular}{|r|l|ll|}
\hline$*: 1-10 \%$ & +: present & Qz: quartz & Chl: chlorite \\
$* *: 10-20 \%$ & -: not present & Fs: feldspar & I: illite \\
$* * *: 20-30 \%$ & Tr: traces & Plag: plagioclase & I/S: mixed layered (illite/smectite) \\
$* * * *: 30-40 \%$ & I/: chemically destroyed & Mc: micas & S: smectite \\
$* * * * *: 40-50 \%$ & & Cc: calcite & V: vermiculite \\
\hline
\end{tabular}


Quartz serves as a non-plastic, in part as filler and in part as glassformer material, decreases the plasticity, facilitates the defloculation and increases the permeability of the ceramic product. The amount of quartz influences the quantity of the amorphous phase after sintering and according to Buhmann et al. (1988), Mitchell (1983), Teixeira et al. (2001) and Das et al. (2005) more quartzitic clays show less shrinkage, with adequate densification and strength values on the ceramic products.

Calcite may provide disadvantages or advantages according to their particle size (Varsos and Sikalidis, 1993). Calcite produces on firing lime $(\mathrm{CaO})$ which slakes in moist air and may crack or "blow" the ceramic product (brick, roof or floor tile). This can be largely avoided in the studied clays because of the fine particle size $(<300 \mu \mathrm{m}$, Sikalidis and Minopoulos, 1998). Further more, the finely divided $\mathrm{CaCO}_{3}$ provides advantages in iron rich clays improving on firing the dark red-brown colour of the product. Calcium compounds act also as binders by glass formation on firing but in excess they may cause premature fusion resulting to distortion of the product. The decomposition of $\mathrm{CaCO}_{3}$ during firing and the evolution of $\mathrm{CO}_{2}$ outside the structure of the fired samples tend to create a more porous structure (Darweesh, 2001; Baccour et al., 2009). Thus, the main effect of the calcareous content, and its decomposition on firing, is to increase the porosity, the water absorption and decrease the linear shrinkage (Sousa and Holanda, 2005). Besides, carbonates form a fusible eutectic with alumina and silica (Yatsenko et al., 1998) and also act as fluxing minerals (Andreola et al., 2009).

Feldspars content proportion is moderate $(<20 \%)$ in RC and moderately high $(20-30 \%)$ in the GC and BC clays. Plagioclases predominate over K-feldspars, in all clay samples. Feldspars are of major importance in reducing melting points (Mitchel, 1983) promoting vitrification (Buhmann and Fey, 1988). They act as a fluxing material, dissolving first the clay substance and finally the flint particles to form mullite in sufficient quantities to improve ware properties. The feldspar type dictates the content of soda $\left(\mathrm{Na}_{2} \mathrm{O}\right)$, potash $\left(\mathrm{K}_{2} \mathrm{O}\right)$ and/or lime $(\mathrm{CaO})$, which in turn influences certain characteristics in the ceramic firing process (Harben, 2002).

Clay minerals along with silica perform a filler function (skeleton formers) of the ceramic articles. Clay size particles of the three clays studied (Table 2) consist of about equal parts of nonexpandable clay minerals (illite and chlorite) and expandable ones (mixed layer illite/smectite, smectite, vermiculite). Illite is one of the major components of clays used in traditional ceramics for the production of cooking pots, plates, tiles and bricks (Ferrari and Gualtieri, 2006). Experimental work by Ferrari and Gualtieri (2006) showed that illite content may determine the percentage of glass phase formed on firing, the linear shrinkage and the water absorption of the fired articles.

\subsection{Chemistry of the clay samples}

The chemical composition and the ignition loss of the investigated clays are shown in Table 3 . These clays consist mainly of $\mathrm{SiO}_{2}$ and $\mathrm{AI}_{2} \mathrm{O}_{3}$ which correspond to 58.64-81.38 wt. \%.

Since a large quantity of alkalis $\left(\mathrm{K}_{2} \mathrm{O}+\mathrm{Na}_{2} \mathrm{O}\right)$ is present $(3.42-4.35 \mathrm{wt} . \%)$, these clays may have an important fluxing action and reach the melting point at lower firing temperatures (Darweesh, 2001; Ferrari and Gualteri, 2005).

The wt.\% of $\mathrm{Fe}_{2} \mathrm{O}_{3}$ is relatively high (5.04 to $6.50 \mathrm{wt} . \%$ ) but regarded as acceptable for use in ceramics. Iron is recognised to possess good fluxing properties and the iron oxide content influences the mechanical strength of the ceramics (Anderson et al., 2009; Andji et al., 2009 and Samara et a1., 2009).

Projection of the chemical composition of the studied clays on the ternary (empirical) discriminant 
Table 3. Chemical analyses of the three compound clay samples

\begin{tabular}{|c|c|c|c|}
\hline \multirow{2}{*}{$\begin{array}{l}\text { Oxide content } \\
w t . \%\end{array}$} & \multicolumn{3}{|c|}{ Clays } \\
\hline & $R C$ & $G C$ & $B C$ \\
\hline $\mathrm{SiO}_{2}$ & 67.29 & 45.57 & 53.38 \\
\hline $\mathrm{Al}_{2} \mathrm{O}_{3}$ & 14.09 & 13.07 & 10.49 \\
\hline $\mathrm{TiO}_{2}$ & 0.76 & 0.68 & 0.52 \\
\hline $\mathrm{MnO}$ & 0.15 & 0.11 & 0.10 \\
\hline $\mathrm{Fe}_{2} \mathrm{O}_{3}{ }^{1}$ & 6.50 & 6.04 & 5.04 \\
\hline MgO & 1.89 & 3.42 & 3.01 \\
\hline $\mathrm{CaO}$ & 1.02 & 13.20 & 11.73 \\
\hline $\mathrm{Na}_{2} \mathrm{O}$ & 1.24 & 1.92 & 2.26 \\
\hline $\mathrm{K}_{2} \mathrm{O}$ & 2.18 & 2.50 & 2.09 \\
\hline $\mathbf{P}_{2} \mathbf{O}_{5}$ & 0.01 & 0.02 & 0.02 \\
\hline L.0.I. ${ }^{2}$ & 4.94 & 13.39 & 11.20 \\
\hline Total & 100.07 & 99.92 & 99.84 \\
\hline
\end{tabular}

${ }^{1}$ Total iron as $\mathrm{Fe}_{2} \mathrm{O}_{3}$

${ }^{2}$ Loss on ignition

diagrams proposed by Sandrolini and Palmonari (1974) and Vincenzini and Fiori (1976) elucidates their suitability for ceramic products (Fig. 3). The BC and GC clays were found to be suitable for faience (earthen ware) ceramics which are products with comparatively high values of apparent porosity. This can be explained by the high calcite contents which after firing decompose to lime and volatile $\mathrm{CO}_{2}$ (Darweesh, 2001; Baccour et al., 2009). The RC having higher quartz content is suitable for gres ceramics.

However, it must be emphasized that conclusions based only on chemical characteristics may lead to misjudgement concerning the suitability of clays for ceramic application. Mineralogical and mainly technological characteristics (e.g. firing tests) are necessary for correct conclusions.

\section{Conclusions}

The need of technologically accepted raw materials for manufactures of building ceramics (bricks, roof and floor tiles etc) or other clay ceramic products, dictates the investigation, study, and evaluation of local clays towards these applications.

Three compound clay samples (red-blue-green) from a quarry in W. Peloponnese were characterized by particle size analysis, mineralogy and bulk chemistry. The clay size fraction $(\mathrm{d}<2 \mu \mathrm{m})$ percentage ranges from 28.3 to $36.3 \mathrm{wt} . \%$.

The clays are of illitic type containing substantial amounts of quartz and calcite (blue and green). The major mineral constituents are quartz, micas, calcite, feldspars and clay minerals. The clay fraction consist mainly of discrete illite and mixed layered I/S.

On the basis of their grain size and specifically on their chemical composition the green and blue clays were found suitable for earthen ware ceramics as are high porosity building bricks, roofing tiles and similar products, while the red clay suitable for gres ceramics. 


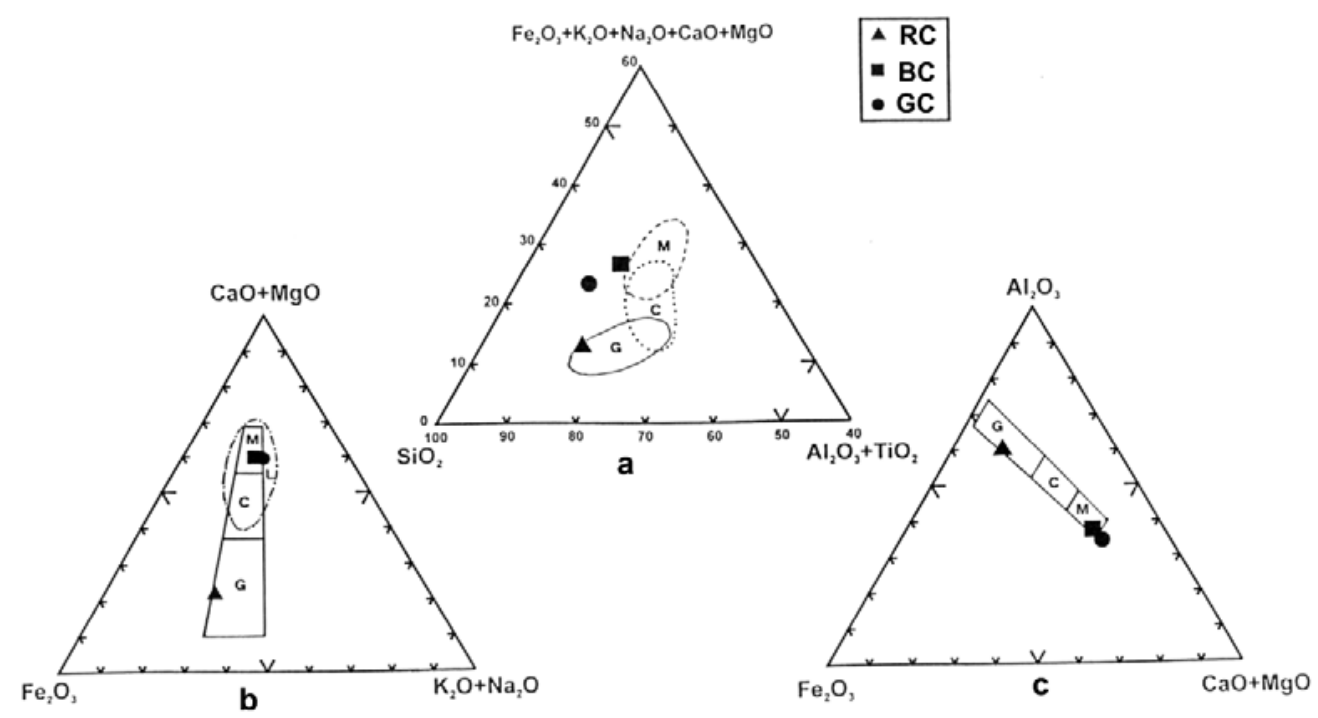

Fig. 3: Projection of the chemical composition of the three compound clay samples on the diagrams: a) $\mathrm{SiO}_{2}$ $\left(\mathrm{Fe}_{2} \mathrm{O}_{3}+\mathrm{K}_{2} \mathrm{O}+\mathrm{NaO}+\mathrm{CaO}+\mathrm{MgO}\right)-\left(\mathrm{Al}_{2} \mathrm{O}_{3}+\mathrm{TiO}_{2}\right)$, b) $\mathrm{Fe}_{2} \mathrm{O}_{3}-(\mathrm{MgO}+\mathrm{CaO})-\left(\mathrm{K}_{2} \mathrm{O}+\mathrm{Na}_{2} \mathrm{O}\right)$ and c) $\mathrm{Fe}_{2} \mathrm{O}_{3}-\mathrm{Al}_{2} \mathrm{O}_{3}-$ $(\mathrm{CaO}+\mathrm{MgO})$ (after Sandrolini and Palmonari, 1974; Vincenzini and Fiori, 1976). M: majiolica, C: cottoforte (semigres), G: gres, F: faiance (earthenware).

\section{Acknowledgments}

Special thanks are due to Dr. D. Papoulis for his constructive comments, resulting in significant improvement of this paper.

\section{References}

AFNOR EN 100, 1982.Careaux et dalles céramiques. Détermination de la résistance à la flexion. 12 pp.

Anderson, M.,Elliott and M., Hickson, C., 2002. Factory scale trials using combined mixtures of three byproduct wastes (including incinerated sewage sludge ash) in clay building bricks. Journal of Chemical Technology and Biotechnology, 77, 345-351.

Andji, J., Abba Toure, A., Kra, G., Jumas, J., Yvon, J. and Blanchart, P., 2009. Iron role on mechanical properties of ceramics with clays from Ivory Coast. Ceramics International, 35, 571-577.

Andreola, F., Siligardi, C., Manfrendini, T. and Carbonchi, C., 2009. Rheological behaviour and mechanical properties of porcelain stoneware bodies containing Italian clay added with bentonites. $\mathrm{Ce}$ ramics International, 35, 1159-1164.

Aras, A., 2004. The change of phase composition in kaolinite- and illite- rich clay-based ceramic bodies. Applied Clay Science, 24, 257-269.

Austin, G., 1994. Adobe and Similar Materials. In: D. D. Carr (ed.). Industrial minerals and rocks $6^{\text {th }}$ ed. Society for Mining, Metallurgy and Exploration, Inc. Littleton, Colorado, 279-286 p.

Baccour, H, Medhioub, M., Jamoussi, F.and Mhiri, T., 2009. Influence of firing temperature on the ceramic properties of Triassic clays from Tunisia. Journal of Materials Processing Technology, 209, 3812-2817. 
Brown, G. and Brindley, G., 1980. X-ray diffraction procedures for clay mineral identification. In: G.B. Breindley and G. Brown (Editors), Crystal Structures of Clay Minerals and Their X-ray Identification. Mineral. Soc., London, 305-360 p.

Buhmann, C., De Villiers, J. and Fey, M., 1988. The mineralogy of four heaving clays. Applied Clay Science., 3 (3), 219-236.

Burst, J., 1991. The application of clay minerals in ceramics. Journal Applied Clay Science, 5, 421-443

Burst, J. and Hughes, R.,1994. Clay-based ceramic raw materials. In: D. D. Carr (ed.). Industrial minerals and rocks $6^{\text {th }} \mathrm{ed}$. Society for Mining, Metallurgy and Exploration, Inc. Littleton, Colorado,317$324 \mathrm{p}$.

Darweesh, H., 2001. Building materials from siliceous clay and low grade dolomite rocks. Ceramics International, 27, 45-50.

Das, S., Dana, K., Singh, N. and Sarkar, R., 2005. Shrinkage and strength behaviour of quartzitic and kaolinitic clays in wall tile compositions. Applied Clay Science 29, 137-143.

Ferrari, S. and Gualtieri, A., 2006. The use of illitic clays in the production of stoneware tile ceramics. Applied Clay Science, 32, 73-81.

Harben, P. W., 2002. The Industrial Minerals. Handy Book A guide to markets, specification and prices. $4^{\text {th }}$ edition. Industrial Mineral Information, London, 409pp.

Jackson, M., 1974. Soil Chemical Analysis. Adv. Course. $2^{\text {nd }}$ ed. Madison, WI, 690pp.

Jordán, M., Sanfeliu, T. and De la Fuente, C., 2001. Firing transformation of Tertiary clays used in the manufacturing of ceramic tile bodies. Aplied Clay Science, 20, 87-95.

Kastrinaki, A., Tsirambides, A., Michailidis, K. and Trontzios, G., 2004. Evaluation of mudstone formations and their suitability for ceramics production. Bulletin Geological Society Greece, $10^{\text {th }}$ International Congress, XXXVI (1), 19-27.

Kromer, H., 1982. Mineralogical and technological characteristics of ceramic clays. International Clay Conference, 685-697 p.

Michailidis. K.,Tsirambides, and Tsamantouridis, P., 1993. Kaolin weathering crusts on gabbroic rocks at Griva, Macedonia, Creece. Applied Clay Science, 8, 19-36.

Mitchel, L., 1983. Ceramic Raw Materials. In: S.J. Lefond, ed. Industrial Minerals and Rocks, $5^{\text {th }}$ (ed.), Vol. 1, , AIME, New York, 33-39 p.

Moore, D. M. and Reynolds R. C. Jr., 1997. X - Ray Diffraction and the Identification and Analysis of Clay Minerals. $2^{\text {nd }}$ ed. Oxford Univ. Press, New York, 378 pp.

Nahdi, K., Gasmi, N. and Trabelsi Ayedi, M., Kbir-Ariguib, N., 2001. Characterization and thermal behaviour of Jebel Ressas clay. Journal of Societe Chimique de Tunisie, 4, 125-134.

Nakagawa, M., 1994. Clay mineral associations and mineralogical properties of quartz in some pottery of western Kyushu, Japan. Aplied Clay Science., 8 (5), 331-347.

Perraki, T., 1987. Study of the mineralogical and technological characteristics of ceramic clays from Attiki, Chalkida and Viotia, Ph. D. Thesis, Nat. Tech. Univ. Athens, Athens.

Perraki, T., 1990. Characteristic of ceramic clays from areas Perivolia and Stalos of Chania Region. Mineral Wealth, 64, 41-47.

Perraki, T. and Orfanoudaki, A., 1996. Evaluation des pates argileuses, en function de leur composition chimique en vue de leur utilization dans la fabrication d'objects ceramiques. Mineral Wealth, 100, 1522.

Samara, M., Lafhaj, Z. and Chapiseau, C., 2009. Valorization of stabilized river sediments in fired clay bricks: Factory scale experiment. Journal of Hazardous Materials, 163, 701-710. 
Sanrdolini, F. and Palmonari C., 1974. Variazioni strutturali e dimensionali durante la cottura di argille italiane per materiali da costruzione. La Ceramica, 17, 6-12.

Schmidt-Reinholz, C. and Schmidt, H., 1985. Suitability tests on raw materials, heavy clay bodies and structural ceramic products. Interbrick, 1, 38-42.

Sikalidis, C. and Minopoulos, P., 1998. Chemical, mineralogical and technological characteristics of natural clays from Macedonia (N. Greece) and their evaluation for utilization in ceramics industry. Mineral Wealth, 107, 47-54

Sousa, S. and Holanda, J., 2005. Development of red wall tiles by the dry process using Brazilian raw materias. Ceramics International, 35. 215-222.

Tanner, C. B. and Jackson, M.L., 1947. Nomographs of sedimentation times for soil particles under gravity or centrifugal acceleration. Soil Science Society Proceedings of America, 60-65.

Teixeira, S., de Sousa, S. and Moura, A., 2001. Mineralogical characterization of clays used in the structural ceramic industry in west of S. Paulo state, Brasil. Cerâmica,47, 204-207.

Teixeira, S., de Sousa, S. and Nobre, M.. 2004. Physical and mechanical properties of ceramics from clays of the west of S. Paulo State, Brasil. Cerâmica, 50, 268-273.

Veniale, F. and Palmonari, C., 1974. Giacimenti di Argolle Ceramiche in Italia. International Association for clay Recearch. . Grupo Italiano A.I.P.E.A. Bologna, 310 pp.

Varsos, D. and Sikalidis, C., 1993. The preparation of ceramic raw materials through the dry process. International Journal of Tile and Brick, 19 (3), 137-140.

Vincenzini, P and Fiori C., 1976 Italian clays for the production of building material. Their characteristics and some technical properties. Ceramurgia, 7 (3), 119-134.

Yatsenko, N., Zubekhin, A. and Rakova, V., 1998. Low shrinkage ceramic tiles. Glass Ceramics 55 (78), 255-257. 